\title{
TAKATUZI, Tatiana. Águas bastismais e santos óleos: uma trajetória histórica do Aldeamento de Atalaia. Curitiba: SAMP, 2014. 228 p.
}

\author{
Adriane do Santos Tavella Ferrari ${ }^{1}$
}

- Enviado em 28/01/2016

- Aprovado em 05/05/2016

O livro “Águas Batismais e Santos Óleos: Uma trajetória histórica do aldeamento de Atalaia" de autoria de Tatiana Takatuzi, traz uma análise documental histórica do processo de ocupação do território nos campos de Guarapuava no Paraná. A autora teve como desafio utilizar fontes documentais oficiais como relatórios, correspondência da coroa portuguesa e governadores da província e relatos de viajantes para compreender os processos de formação do aldeamento de Atalaia e seus atores sociais. Seguindo uma perspectiva cronológica e histórica parte de uma extensa pesquisa descrevendo o processo de ocupação do território, o surgimento e a desagregação do aldeamento de Atalaia.

O livro é composto por três capítulos, e anexos com transcrições de cartas régias que tiveram grande influência nas práticas indigenistas desse período.

O primeiro capítulo denominado de "Frentes de expansão para os campos de Guarapuava" faz uma narrativa histórica do processo de ocupação territorial como as estratégias de aproximações dos brancos com os índios e as políticas indigenistas vigentes no final do século XVIII e início do século XIX. A autora destaca, através de documentos, as formas de contatos das primeiras expedições, trocas de brindes e as práticas inconstantes de uma política indigenista que marcam esse período e como os índios Kaingang respondiam a esse momento. A visão estereotipada e etnocêntrica desse período marca o indígena como "inferior” e sujeito a uma postura de subjugação.

\footnotetext{
${ }^{1}$ Graduada em Ciências Sociais pela Universidade Federal do Paraná/UFPR. Especialista em Antropologia Cultural pela PUC-PR. Endereço eletrônico: adrianeferrari2045@gmail.com 
Mas, através dos relatos dos viajantes a autora aponta como os indígenas articulavam-se e organizavam-se diante dos brancos. Por exemplo, a emboscada realizada na expedição de Afonso Botelho e o massacre desse grupo pelos Kaingang, ou ainda, de que forma as trocas de mercadorias com os brancos eram na verdade uma forma de incorporação desses bens estrangeiros conforme suas necessidades. Ao contrário do que pensavam os europeus não significava a dominação pois, não representavam mudanças significativas em suas vidas.

A questão da política indigenista do início do século XIX é bastante conturbada. As práticas políticas são marcadas, de um lado, por interesses de uma sociedade que buscava a expansão campeira e agrícola com a instalação de fazendas de criação de gado nos Campos Gerais e Guarapuava e de outro, por um Estado preocupado em marcar fronteiras territoriais. Assim, por seu lado os fazendeiros entendiam que os índios Kaingang em seus territórios eram um empecilho para o desenvolvimento econômico da região, e de outro, o Estado Monárquico determinava leis sobre o tratamento que deveria ser aplicado aos índios através de duas Cartas Régias tem tinham entre seus objetivos selecionar os gentios de guerra e os que serviriam como mão-de-obra indígena, expandir as fronteiras e estruturar a sociedade campeira. Todo esse período é marcado por momentos contraditórios de uma política indigenista inconstante com práticas diferenciadas conforme os interesses do Estado: o período pombalino, as reformas do diretor de aldeamentos Rendom, duas Cartas Régias e pelo conceito do projeto de nação proposto por José Bonifácio. E foi nesse contexto, com uma política indigenista que ora determinava o extermínio e o aprisionamento dos índios, ora pregava a catequese e a civilização para a integração do índio à sociedade nacional., que surgiu o Aldeamento de Atalaia.

O segundo capítulo "Vivências em Atalaia: aspectos da catequese" destaca a trajetória do padre Francisco das Chagas, seu trabalho de catequese e suas relações com os Kaingang e a população local. O padre tinha grande prestígio junto ao clero e ao governo da capitania de São Paulo o que lhe rendeu a nomeação para dirigir o aldeamento. Esse capítulo é construído a partir de pesquisas dos registros de casamentos e batizados do Aldeamento de Atalaia nos quais o padre Francisco das Chagas classificava os índios como aldeados e não aldeados. O padre Chagas também organizou pelos registros um levantamento de dados populacionais e dados de formação étnica dos grupos Kaingang que viviam ou perambulavam pelo aldeamento nesse período. Ainda destacando a importância dos registros, foi possível observar as classificações entre os grupos Kaingang entre: batizados, catecúmenos, semi-bárbaros e bárbaros. 
A trajetória do padre Francisco das Chagas no aldeamento de Atalaia é marcada por diversas dificuldades. Entre seus problemas da administração do aldeamento estavam os enfrentamentos com os soldados devido a má conduta moral cristã do grupo militar que atrapalhava o processo de catequização, e os problemas com a população que defendia o aprisionamento dos índios, prática contrária à adotada pelo padre Chagas. O processo de catequização impunha a adoção de alguns hábitos cristãos como casamentos e batismos, não apesar da adoção desses, isso não significava conversão, pois muitos índios após o batismo retornavam aos sertões. Segundo a autora, o padre Francisco das Chagas utilizava de artifícios para justificar o seu trabalho de catequização. Os diversos registros de casamentos e batizados, demonstram estratégias desse padre em fazer esses registros com dados para "disfarçar" a poligamia. Por exemplo, registrava as mulheres índias como viúvas, pais incógnitos, pai falecido para registrar o batismo das crianças. Ou ainda fazer casamentos Inter étnicos entre escravos e índios na tentativa de frear a promiscuidade, não aceita pelo processo de catequização.

No terceiro capítulo: "Dispersão e declínio" a autora, relata os grandes desafios encontrados pelo projeto de catequização do aldeamento que eram a poligamia, guerras e alianças entre os Kaingang. A poligamia sempre foi o grande desafio do padre Francisco das Chagas na implantação da catequização dos Kaingang no Aldeamento Atalaia. Em 1812 uma grande epidemia (gripe, varíola, sarampo entre outras doenças) dizimou um grande número de índios Kaingang e originou também uma grande debandada do aldeamento. Com o grande número de mortos devido a epidemia, o ritual do kiki que marca a transição dos mortos caracteriza-se como uma forma de marcar sua cosmologia e as normas religiosas do aldeamento. Essa grande baixa da população do aldeamento transformou os núcleos familiares, menores devido ao grande número de órfãos e por consequência a diminuição da poligamia. O padre Francisco das Chagas utilizava a poligamia, como uma forma de classificar e hierarquizar os índios dentro do aldeamento pois, os polígamos eram selvagens e pagãos, enquanto que os monógamos eram "mais" civilizados e mais fáceis a subordinação do sistema da igreja.

Ao contrário do que pensavam os religiosos, os índios que se converteram aos sacramentos da igreja na verdade, adaptaram as normas religiosas a sua cosmologia. Assim, utilizavam a "conversão" como uma estratégia de buscar um espaço de negociação junto aos brancos. Existia uma grande mobilidade dos índios do aldeamento, mesmo os índios batizados e casados conforme padrões cristãos católicos permaneciam com esse hábito. Essa mobilidade era marcada por diversos fatores: proibição da poligamia, guerras intertribais, trabalho compulsório, busca por novas 
mulheres e uma economia baseada em caça, pesca e coleta por isso, tinham o hábito de migrar quando acabavam os recursos.

O Aldeamento do Atalaia era um ponto estratégico dentro dessa mobilidade Kaingang pois, muitos índios aldeados estabeleciam uma comunicação entre os índios aldeados e não aldeados. A circulação era um elemento essencial para estabelecer uma rede de relações com a população branca e mercadorias. As guerras entre os diversos grupos Kaingang é marcada pelas diferenças entre Kamés, Votorões e Cayeres. Essas guerras têm por consequência a destruição do Aldeamento de Atalaia e o aprisionamento dos grupos inimigos o que contribuiu para a utilização da mão de obra indígena pelos fazendeiros. Muitas vezes, como resultado dessas guerras surgia uma aliança entre brancos e índios pelo casamento entre brancos e filhas de chefes indígenas, o que na verdade era o resultado de um jogo de interesse de ambos. As alianças caracterizavam as relações entre sogros e genros, o que determinava a atuação política do grupo. No Aldeamento de Atalaia os índios dividiam as alianças, o domínio territorial e a atuação política dos diversos grupos. Dessa forma os índios "ditaram" as regras de funcionamento do aldeamento.

A crescente implementação da sociedade agropastoril nos Campos de Guarapuava despertou o interesse de novas apropriações das terras para a formação de novos núcleos. Esse é o novo cenário que marca o fim do Aldeamento de Atalaia. O grande desafio da autora foi realizar uma problematização documental de fontes oficiais e praticar o exercício da desconstrução por meio de uma análise do processo de colonização. Esse exercício traz "voz" ao índio que o torna um sujeito ativo com estratégias e atuações em suas relações com os agentes coloniais. 